\title{
Restoration of Al-Sanaf Marsh under Various Operation Conditions
}

\author{
Jamal S. Makki ${ }^{1 *}$, Alkhafaji R. Abood', Mohammad H. AL-Umar ${ }^{1}$ \\ 1 University of Thi-Qar, College of Engineering, Nasiriyah, Iraq \\ * Corresponding author's e-mail: jamal_sahib2000@yahoo.com
}

\begin{abstract}
The dried Iraqi marshlands were re-flooded after the year 2003. Because of the water shortage feeds the marshes during the last years, the re-flooded marshes began to dry again. The Al-Sanaf marsh is part of the Al Hammar marsh located in the Thi Qar province. It is not separated hydraulically from the Al Hammar marsh. The study suggested separating the two marshes by replacing the culverts under security dyke with uncontrolled weir to keep the area of Al-Sanaf marsh submerged. If there is any added water, it will cross from the suggested structure to the Al Hammar marsh. A hydrodynamic and water quality routing models (RMA2 and RMA4) were prepared based on mass conservation low, mass balance model, and four scenarios were applied for the Al-Sanaf marsh based on the incoming discharges. The suggested model was calibrated with field data measured in the marsh. The four suggested scenarios are to keep the requirement of the Al-Sanaf marsh restoration. The maximum submerged area of the marsh is $100 \mathrm{~km}^{2}$ under any operation conditions while this area was reduced to $72 \mathrm{~km}^{2}$ under low flow conditions (minimum inflow from the feeders). The three scenarios operated considering values of inflow from Euphrates River with the required inflow from Al Khamissiya canal to keep the minimum level of salinity in the submerged area. While the fourth scenario operated with the minimum value of discharge from all feeders.
\end{abstract}

Keywords: Al-Sanaf Marsh; hydrodynamic mode, Marshland, Al Hammar Marshes, RMA2, RMA4

\section{INTRODUCTION}

The marshlands of Iraq are located in the southern part at the confluence of Euphrates and Tigris rivers. They cover an area of about 15000-20000 km²(Yasir, Rahi, \& Abudi, 2018). The Mesopotamia marshlands denote the largest wetland ecosystem in the Middle East and western Eurasia (Hussain \& Ali, 2006; Marghany, Hasab, Mansor, \& Shariff, 2016). Three major marsh areas are considered the core of the wetlands of Iraq Al Hammar Marshes; the Central Marshes and the Al Hawizeh Marshes (Kugaprasatham, Al-Lami, \& Aoki, 2014). Each major marsh zone consists of hydraulically connected shallow lakes and scattered ponds (Yasir et al., 2018).

The Tigris and Euphrates Rivers and their branches are the main source of water feeding the marshes, but the inflows to the marshes reduced on the last two decades of the past century because of the construction of major hydraulic structures and dams at the upstream zone of both rivers in
Turkey and Syria (Al-Ansari, 2013; Al-Ansari \& Knutsson, 2011).

In addition, the marshes were destroyed by the series of combined impact of huge drainage works carried out in the southern part of Iraq from 1980 to 1990 by the previous regime and upstream damming (Yasir et al., 2018). After 1991 and due to political reasons, the Sadaam regime started implementing five major drainage projects to prevent or reduce the water from the Tigris and Euphrates Rivers to reach the marchland area (Ali, 2013).

As a result of these scenarios, the slowdown destruction carried out by the government during the $1990 \mathrm{~s}$, the decreasing of wetland reached less than $15 \%$ of the natural wetland extent, which was an environmental disaster and reached about $10 \%$ by the year 2001 of the original area (Kadhim, 2005; Curtis J Richardson, 2016).

In April 2003, directly after the fall of the Saddam's regime, the dikes and earthen dams were broken by farmers and local populations 
releasing water return into many former marsh areas (Curtis J Richardson, 2016). As well as the Iraqi government with the assistant of other countries and international organizations started the process of restoration and rehabilitation of Iraqi marshes (Al-Ansari \& Knutsson, 2011) and encourage people to return live in these area. Approximately $20 \%$ of the $15,000 \mathrm{~km}^{2}$ of the former dried marshes had been re-flooded by early 2004 (Curtis J. Richardson \& Hussain, 2006).

The Al Hammar marsh is one among the three marshes that constitute the formerly extensive and biodiverse Mesopotamian marshlands of southern Iraq (Al-Musawi, Al-Obaidi, \& Al-Rubaie, 2018). It is located in the south direction of the Euphrates river, expanding from the west of Nasiriyah city into the borders of Basrah on Shatt Al-Arab in the east (Al-Ansari, Knutsson, \& Ali, 2012). The marshland varying from $2800 \mathrm{~km}^{2}$ of permanent marsh, expanding to $4500 \mathrm{~km}^{2}$ during wet periods (Azhar Al-Saboonchi et al., 2011). The maximum water depth in the marsh varies from $1.8 \mathrm{~m}$ to $3.0 \mathrm{~m}$ (Foundation, 2003; Najah et al., 2009). Al Hammar marsh had been dried for over a decade, but it was reconditioned to near half its original size in the year of 2005 after a policy of restoration of marshland was initiated to recover the marshes in 2003 (Al-Gburi, Al-Tawash, \& Al-Lafta, 2017). In 2002, 93\% of the permanent marshes existed in 1973 had been dried and destroyed and most of people living in these area were moved to another areas. For Al Hammar marsh, not more than $14.5 \%$ of original area remained (Richardson and Hussain 2006). After 2003, excessive hard work and activities have been made to reestablish the marshes and revive the wetlands environment. These activities were succeed in 2007 for recovering almost $58 \%$ of their former area from 1972, according to UNEP/ IMOS (2007) (Mohamed \& Hussain, 2012).

Furthermore, a cooperative between the United Nations Environment Program (UNEP) and United Nations Educational, Scientific and Cultural Organization (UNESCO) has been created to confirm sustainable improvement of the Marshlands in Iraqi by introducing them into the World Heritage List, as these sole wetlands represent a region of outstanding universal historical, cultural, environmental, hydrological, and socio-economic value (Al-Gburi et al., 2017; UNEP-DTIE-IETC, 2009).

In spite of the strenuous efforts from the local authorities and International Agencies to restore the marshland to the previous situation, but all of these efforts failed due to the water crisis of the water resources which supply water to the marshland.

Due to the drought conditions between 2005 and 2009, the water supplies to the marshlands were decreased, which distraught agriculture area and caused a big shortages for supplying a drinking water, mainly in rural areas. Therefore, around $39 \%$ of farming field suffered a reduction in coverage for two years in sequence between 2007 and 2009, and livestock has been decimated (Al Obaidy \& Al-Khateeb, 2013). Fifty percent of the existing surface water in Iraq comes from the upstream rivers in the neighboring countries of Turkey and Iran, which directly affects the downstream rivers and the marshland in the lower zone of Iraq.

In the case of scarcity, the small amounts of water are distributed over all the area of the $\mathrm{Al}$ Hammar Marshes scattered on sporadic ponds not useful for different purposes. Therefore, the idea of this research is to make the part of this area of the marshes permanent, by separating the Al-Sanaf marsh from the Al Hammar Marshes and any amount of coming water will be enough to keep it as permanently immersed. If there is more water, it will cross to the Al Hammar Marshes. Thus, the existence of permanent marsh will be ensured and it will help protect the ecosystems in marsh.

This situation leads for thinking of new scenario to keep minimum area from marshland which is the main objective of this study taking Al-Sanaf marsh as a sample to study the restoration of it under various operation conditions. As a result, Authors of the current study hope that it could contribute to the management process, which not only meets the technical requirements of the World Heritage Convention, but will also introduce a new motivation to the efforts that target at protecting and preserving the environment and live conditions in the Mesopotamian Marshes.

\section{MATERIAL AND METHODS}

\section{Description of the marsh}

The Al-Sanaf marsh is located in Thi-Qar governorate between $\mathrm{E}=635237$ to $\mathrm{E}=636235$ and $\mathrm{N}=3401350$ to $\mathrm{N}=3417030$ with an area about $110 \mathrm{~km}^{2}$. The boundaries of the marsh are 
the Euphrates River in Suq AshShuyukh city as a north boundary, the Al Hammar marsh as an east boundary, the Main Outfall Drain (MOD) as the south boundary, and Suq AshShuyukh city as the west boundary, Figure 1 shows the general layout of the Al-Sanaf Marsh. The water from many feeders supplies the marsh; these feeders are Um Elwada and Al Kurmashia from Euphrates River and Al Khamissiya from main outfall drain,
MOD. Al-Sanaf marsh was considered as a part of the Al Hammar marsh where there is no barrier between them. Over the last two decades, the earth dike with four culverts, called Security dike, was constructed between the two marshes. There are three small islands and deep waterway in the marsh. Another obstruction in the marsh is a railway with six box culverts, as shown in Figure 1 (Ministry of Water Resources \& . 2006).

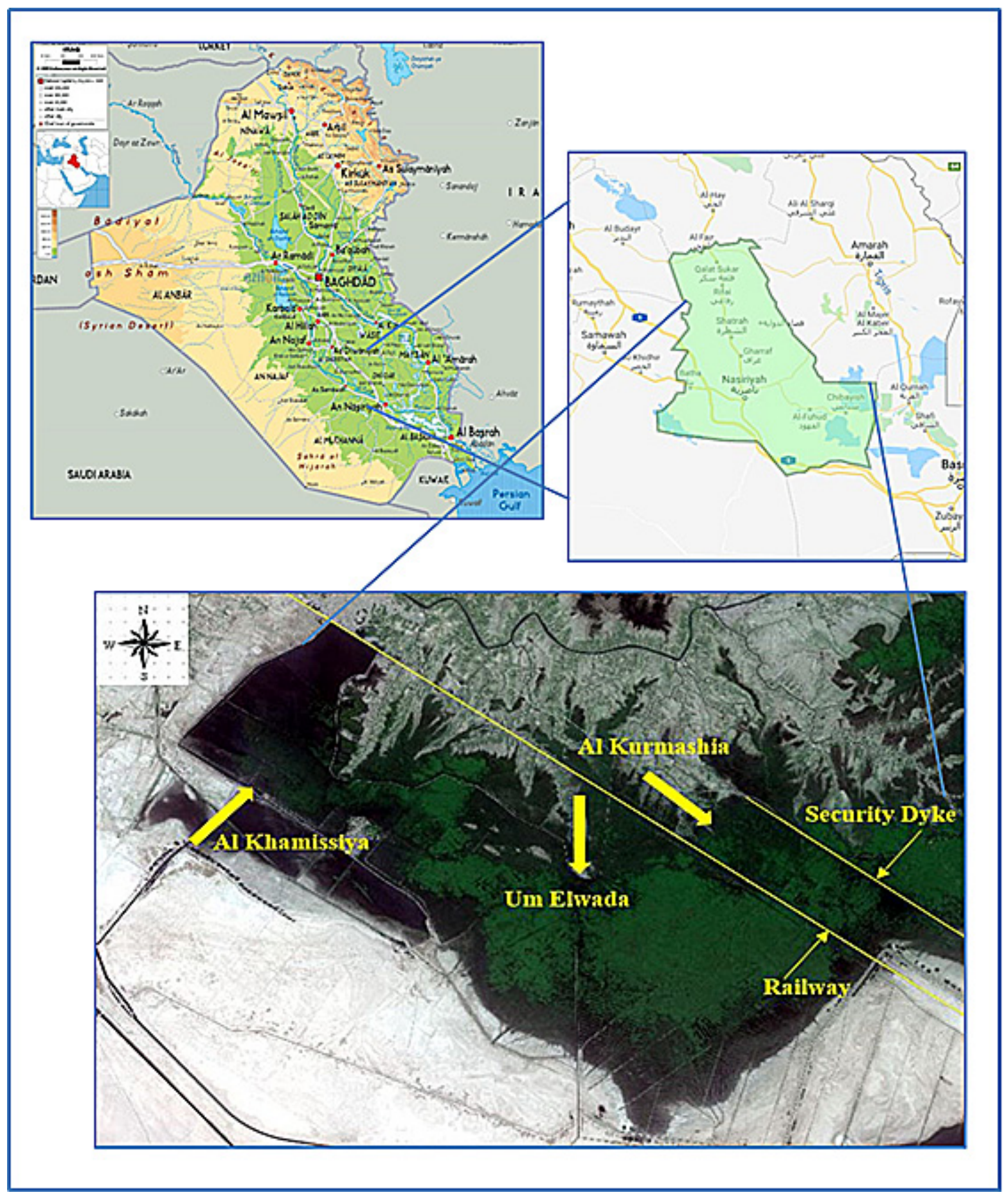

Fig. 1. Layout of the main feeders of AsSanna'f Marsh 


\section{Colected data}

Topographical data, evapotranspiration (ETo) inside the marsh, discharge of the feeders to the marsh, and concentration of total dissolved solids (TDS) in marsh feeders, which are obtained from Center for the Restoration of Iraqi Marsh lands (CRIMW) (CRIM, 2010) as listed in Table 1. The digital elevation model (DEM), which was obtained from Shuttle Radar Topographical Mission Data of 90 meters definition. Alhamadani (Alhamdani, 2014) suggests Manning's roughness coefficients of the bed in marshland using the roughness-depth relationship which is shown in Figure 2.

\section{Field work}

The field investigation was carried out to update the collected data of the marsh with such features as topographical data, and marsh feeders. The islands, waterway, and distribution of vegetation are new features represented in the mathematical model. The topographical data is updated by surveying some locations and comparing them with the available DEM. In order to verify and calibrate the mathematical model, the discharge of the feeders and water depth within the marsh were observed. The discharges of Um Elwada, Al Kurmashia, and Al Khamissiya were measured by using a universal current meter model 6500 , manufactured by Rickly Hydrological Company based on the midsection method of the U.S. Geological Survey (USGS, 1976). Figure 3 (a) shows a snapshot during the process of discharge measurement. Five points through the marsh were selected to check the water depth and TDS. The locations of these points were specified using a GPS device. Figure 3 (b) shows the locations of the points within the marsh. A scaled staff was used to measure the water depth, Figure 3 (c). The water samples were collected at a depth of $5 \mathrm{~cm}$ below the water surface by using a plastic bottle then the total dissolved solids were measured using a Senso Direct 150 multi meter device. Table 2 and 3 represented the measured discharges and DTS of the feeders and water depth with TDS at the tested points through the marsh.

\section{HYDRODYNAMIC AND WATER QUALITY MODELS}

This part describes the development of numerical models capable of accurately simulating the hydrodynamic behavior and water quality variation within the Al-Sanaf Marsh. Two software packages were used for the mathematical simulation purposes, namely:

- The Waterway Experiment Station, WES, RMA2 two-dimensional, finite element numerical model was used in order to determine the elevation of water surface, water depth and

Table 1. Discharge and concentration of total dissolved solids (TDS) in marsh feeders

\begin{tabular}{|c|c|c|c|c|c|c|c|}
\hline \multirow[b]{2}{*}{ No. } & \multirow[b]{2}{*}{ Feeder } & \multicolumn{2}{|c|}{ Location of feeding } & \multicolumn{3}{|c|}{ Discharge, $\mathrm{m}^{3} / \mathrm{s}$} & \multirow{2}{*}{$\begin{array}{c}\text { Average } \\
\text { annual concentration of TDS, } \\
\mathrm{mg} / \mathrm{l}\end{array}$} \\
\hline & & $E$ & $\mathrm{~N}$ & Max. & Min. & $\begin{array}{l}\text { Average } \\
\text { annual }\end{array}$ & \\
\hline 1 & Um Elwada & 646169 & 3409336 & 29.6 & 3.0 & 13.3 & 2535 \\
\hline 2 & $\begin{array}{l}\text { Al-Kurmashia } \\
\text { Canal }\end{array}$ & 649135 & 3411477 & 3.9 & 0.4 & 1.8 & 2550 \\
\hline 3 & Al-Khamissiya & 637326 & 3412079 & 56.6 & 9.7 & 26.4 & 4740 \\
\hline
\end{tabular}

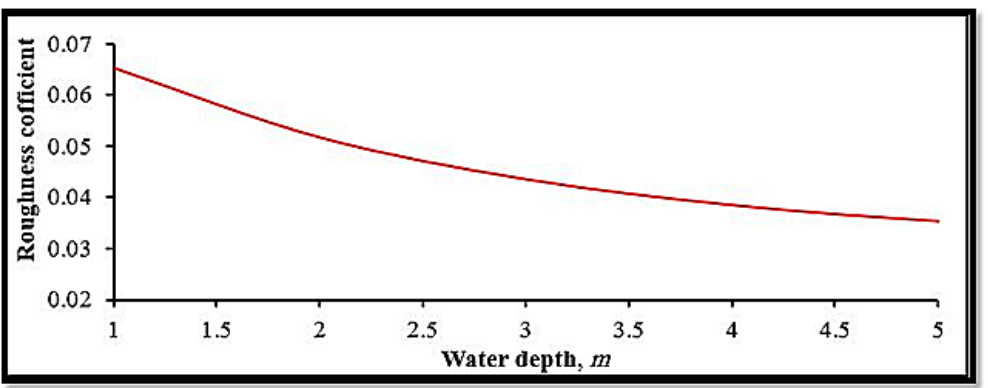

Fig. 2. Manning's Roughness Coefficients for Al-Sanaf marsh 
velocity (magnitude and direction) throughout the marsh.

- The Waterway Experiment Station, WES, RMA4 two-dimensional, finite element numerical water quality model was used to investigate the distribution of TDS inside the marsh. The two above-mentioned models were developed by Norton, King and Orlob of Water Resources Engineers, for the Walla District Corps of Engineers, and delivered in 1973, (Donnell, 2009).

\section{Governing Equations}

The governing equations used in the mathematical model, RMA2 are the momentum and continuity equation.

The momentum equations in both $\mathrm{x}$ and $\mathrm{y}$ directions are

$$
\begin{aligned}
& \mathrm{h} \frac{\partial \mathrm{u}}{\partial \mathrm{t}}+\mathrm{hu} \frac{\partial \mathrm{u}}{\partial \mathrm{x}}+\mathrm{hv} \frac{\partial \mathrm{u}}{\partial \mathrm{y}}-\frac{\mathrm{h}}{\rho}\left[\operatorname{Exx} \frac{\partial^{2} \mathrm{u}}{\partial \mathrm{x}^{2}}+\operatorname{Exy} \frac{\partial^{2} \mathrm{u}}{\partial \mathrm{y}^{2}}\right]+ \\
& +\operatorname{gh}\left(\frac{\partial \mathrm{a}}{\partial \mathrm{x}}+\frac{\partial \mathrm{h}}{\partial \mathrm{x}}\right)+\frac{\operatorname{gun}^{2}}{\left(1.486 \mathrm{~h}^{1 / 6}\right)^{2}}\left(\mathrm{u}^{2}+\mathrm{v}^{2}\right)^{0.5}- \\
& -2 \mathrm{~h} \omega \mathrm{v} \sin \varnothing=0
\end{aligned}
$$

And

$$
\begin{aligned}
& \mathrm{h} \frac{\partial \mathrm{v}}{\partial \mathrm{t}}+\mathrm{hu} \frac{\partial \mathrm{v}}{\partial \mathrm{x}}+\mathrm{hv} \frac{\partial \mathrm{v}}{\partial \mathrm{y}}-\frac{\mathrm{h}}{\rho}\left[\operatorname{Eyx} \frac{\partial^{2} \mathrm{v}}{\partial \mathrm{x}^{2}}+\operatorname{Exy} \frac{\partial^{2} \mathrm{v}}{\partial \mathrm{y}^{2}}\right]+ \\
& +\operatorname{gh}\left(\frac{\partial \mathrm{a}}{\partial \mathrm{y}}+\frac{\partial \mathrm{h}}{\partial \mathrm{y}}\right)+\frac{\mathrm{gvn}^{2}}{\left(1.486 \mathrm{~h}^{1 / 6}\right)^{2}}\left(\mathrm{u}^{2}+\mathrm{v}^{2}\right)^{0.5}- \\
& -2 h v \omega v \sin \varnothing=0
\end{aligned}
$$

The continuity equation in unsteady flow problems is:

$$
\frac{\partial h}{\partial t}+h\left(\frac{\partial u}{\partial x}+\frac{\partial v}{\partial y}\right)+u \frac{\partial h}{\partial x}+v \frac{\partial h}{\partial y}=0
$$

While the governing equation that used in the mathematical model, RMA4 is the depth-averaged transport and mixing equation:

$$
\begin{array}{r}
h\left[\frac{\partial c}{\partial t}+u \frac{\partial c}{\partial x}+v \frac{\partial c}{\partial y}-\frac{\partial}{\partial y}-\frac{\partial}{\partial x}\right. \\
\left.D_{x} \frac{\partial c}{\partial x}-\frac{\partial}{\partial y} D_{y} \frac{\partial c}{\partial y_{c}}+\frac{R(c)}{h}\right]=0
\end{array}
$$

Where $\mathrm{h}$ is represent water depth; $\mathrm{u}$ and $\mathrm{v}$, are referring to velocities in Cartesian coordinates;
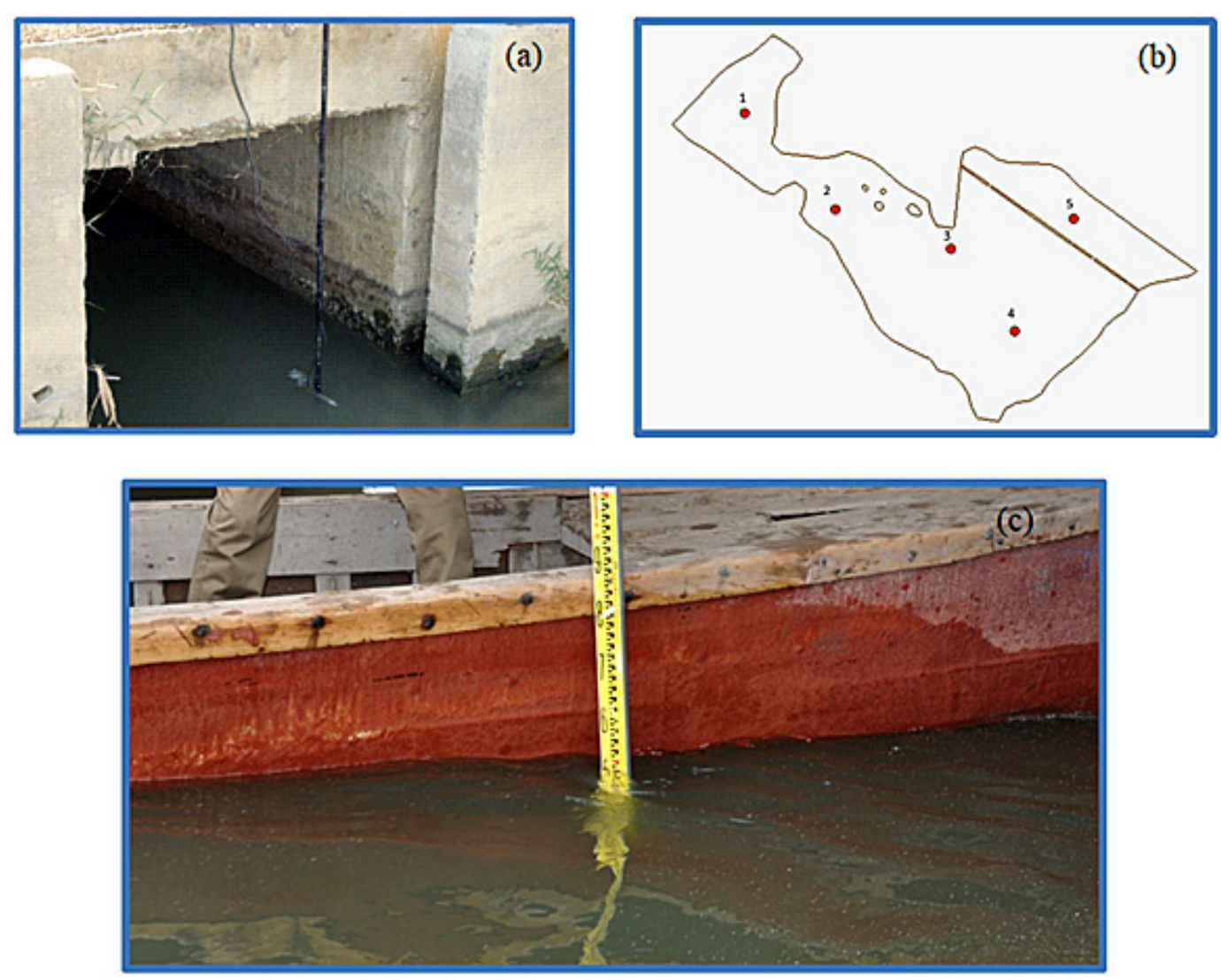

Fig. 3. Field work (a- flow measurement, b- point location, c- water depth measurement 
t, time; $\rho$, density of fluid; Exx, eddy viscosity coefficient on $\mathrm{x}$ axis surface; Eyy, eddy viscosity coefficient on y axis surface; Exy and Eyx, shear direction on each surface; $g$, acceleration due to gravity; a, elevation of bottom; n, manning's roughness; $\omega$, rate of earth angular rotation; $\varphi$, local latitude; c, concentration of pollutant for a given constituent; Dx and Dy, turbulent mixing, dispersion, coefficients; Kc, first order decay of pollutant; $\mathrm{R}(\mathrm{c})$, rainfall/evaporation rate and $\sigma$, source/sink of constituent.

The continuity and momentum equations solved the equations by using the finite element technique, using the Galerkin method of weighted residuals. The quadratic and linear shape functions were used for interpolation of flow velocities and water depths. Fully implicit solution and the set of simultaneous equations were solved by Newton-Raphson nonlinear iteration. As with the continuity and momentum equations, the equation of transport and mixing solved with the finite element method using Galerkin weighted residuals. The transport model handles one-dimensional segments, two-dimensional quadrilateral or triangles curved lament edges. Spatial integration of the equations is performed by Gaussian techniques, (Donnell, 2009).

\section{Model Parameters}

The parameters of RMA2 and RMA4 models are the hydraulic characteristics of the water bodies that are represented in the equations of motion and transport and mixing process. These

Table 2. The measured discharges and TDS of the feeders

\begin{tabular}{|l|c|c|}
\hline \multicolumn{1}{|c|}{ Feeder } & $\begin{array}{c}\text { Measured } \\
\text { discharge, } \mathrm{m}^{3} / \mathrm{s}\end{array}$ & $\begin{array}{c}\text { Concentration of } \\
\text { TDS, } \mathrm{mg} / \mathrm{l}\end{array}$ \\
\hline Um Elwada & 10.7 & 2650 \\
\hline $\begin{array}{l}\text { Al-Kurmashia } \\
\text { Canal }\end{array}$ & 2.1 & 2800 \\
\hline Al-Khamissiya & 18.7 & 5200 \\
\hline
\end{tabular}

parameters cannot be estimated directly in the field, but can be identified after developing the finite element mesh and specifying the boundary conditions depending on previous studies, then checked after the calibration process. Some of these parameters include Manning's roughness (n), turbulent exchange coefficients, and eddy viscosity. The effects of wind, decay of pollutant and source of constituent were not considered.

\section{Boundary Conditions}

There are several boundary conditions from which can be specified at each node in the hydrodynamic model. These conditions including: Parallel flow boundary condition, flow boundary condition, water level boundary condition, stagnation point boundary condition, reflection/ absorption boundary condition, wind field boundary condition and wave field boundary. The water level boundary condition is typically assigned along the downstream boundary nodes of the network while boundary nodes along the upstream end of the network are typically assigned an exact flow boundary condition. The concentration of the pollution can be specified as a boundary condition for water quality model when the water is entering the model.

\section{Hydrological Analysis}

Depending on the principle of mass conservation law, the hydrological routing to Al-Sanaf marsh, the discharges of feeders that incoming from Euphrates River and Al Khamissiya were computed to maintain the constant submerged area of the marsh. This amount of inflow water must be equal to the evapotranspiration, ETo from the marsh add to the minimum monthly outflow requirements to flushing the accumulated salts in the marsh. This hydrological routing was established in four scenarios, three scenarios by taking the minimum, average and maximum annual

Table 3. The measured water depth and TDS at the tested points through the marsh

\begin{tabular}{|c|c|c|c|c|}
\hline \multirow{2}{*}{ Point } & \multicolumn{2}{|c|}{ Location } & \multirow{2}{*}{ Measured water depth, $\mathrm{m}$} & \multirow{2}{*}{ Concentration of TDS, mg/l } \\
\cline { 2 - 3 } & $\mathrm{E}$ & $\mathrm{N}$ & 0.40 & 5850 \\
\hline 1 & 638050 & 3413947 & 0.43 & 5100 \\
\hline 2 & 641967 & 3410030 & 0.88 & 3020 \\
\hline 3 & 646797 & 3408849 & 1.17 & 5200 \\
\hline 4 & 649547 & 3404526 & 1.61 & 3510 \\
\hline 5 & 651575 & 3409470 & \\
\hline
\end{tabular}


discharge of the feeders from Euphrates River with calculated discharge from Al Khamissiya canal (salty water) to maintain the submerged area. Under these scenarios, the minimum monthly discharge of outflow is $5 \mathrm{~m}^{3} / \mathrm{s}$ and submerged area equals $100 \mathrm{~km}^{2}$. The forth scenario is made by taking the minimum inflow from both Euphrates River and Al Khamissiya canal with no outflow in Jun to maintain the submerged area of $72 \mathrm{~km}^{2}$.

\section{RESULTS AND DISCUSSION}

\section{Data analysis}

The topography of the Al-Sanaf marsh was developed based on the available digital elevation model (DEM), which was obtained from Shuttle Radar Topographical Mission Data of 90 meters definition, shown in Figure 4. it was updated according to the obtained data from CRIMW and Alhamdani (Alhamdani, 2014; CRIM, 2010).

Since the Al-Sanaf marsh is a part of the Al Hammar marsh, the data of evapotranspiration and precipitation can be applicable. Figure 5 (a) shows the monthly mean evapotranspiration within the marsh based on the data obtained. From this figure, it can be noted that the maximum value of evapotranspiration is $458 \mathrm{~mm}$ during June. General Iraqi Meteorological Authority and Seismology provided the precipitation within the study area as shown in Figure 5(b). As shown in the figure, the annual amount of the precipitation is less than $100 \mathrm{~mm}$, which means the area can be categorized as dry.

\section{Area and Storage Elevation Curves}

The elevation-storage curve is one of the most significant physical properties of any reservoir.
Depending on the updating DEM of the Al-Sanaf marsh, the area elevation curve was obtained, as shown in Figure 6 the relation of the curve is non-linear.

\section{Calibration of mathematical models}

Calibration refers to the adjustment in values of the parameters that have lack of certainty. As part of the calibration process under the same conditions, the model input parameters were adjusted to obtain a close match between the simulated and observed/measured data (Novikov \& Bagtzoglou, 2006). The calibration process involved 8 iterations; each one has an adjusted value of Peclet Number. The selected values of Peclet Number to be used in next model runs are those that give minimum error between the measured values and that by the models. The measured water depths were used in the calibrating process in RMA2 model runs. The minimum value of error between the measured water depths and results of the model runs were obtained with the Peclet Number of 23. Figure 7 (a) shows measured water depths versus the RMA2 model results. The slight difference between the measured and calculated water depth is because of the inaccurate marsh topography at some points.

The set of concentration of TDS data that was measured was used to calibrate the value the Peclet Number in the RMA4 model runs. The minimum error between the measured data and results of the model runs were obtained with a Peclet Number of 20. Six iterations were made to reach this value. Figure 7 (b) shows the concentration of TDS of field measurements versus that of the RMA4 model results, when using the calibrated values of Peclet Number in the runs of the RAM4 model. The maximum percentage of error was $12 \%$ at point 3 because of this point is quickly affected by the Um Elwada feeder.

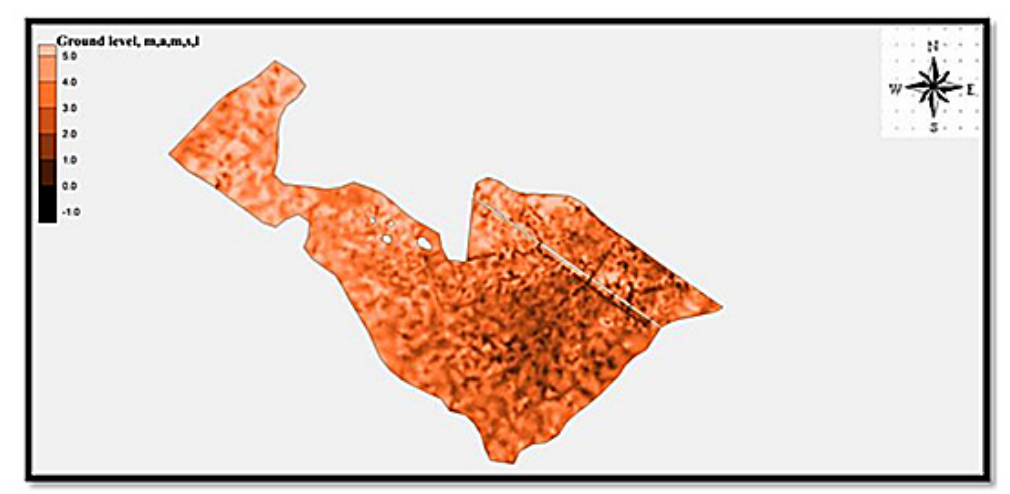

Fig. 4. The topography of Al-Sanaf after CRIMW and Alhamdani (Alhamdani, 2014; CRIM, 2010) 

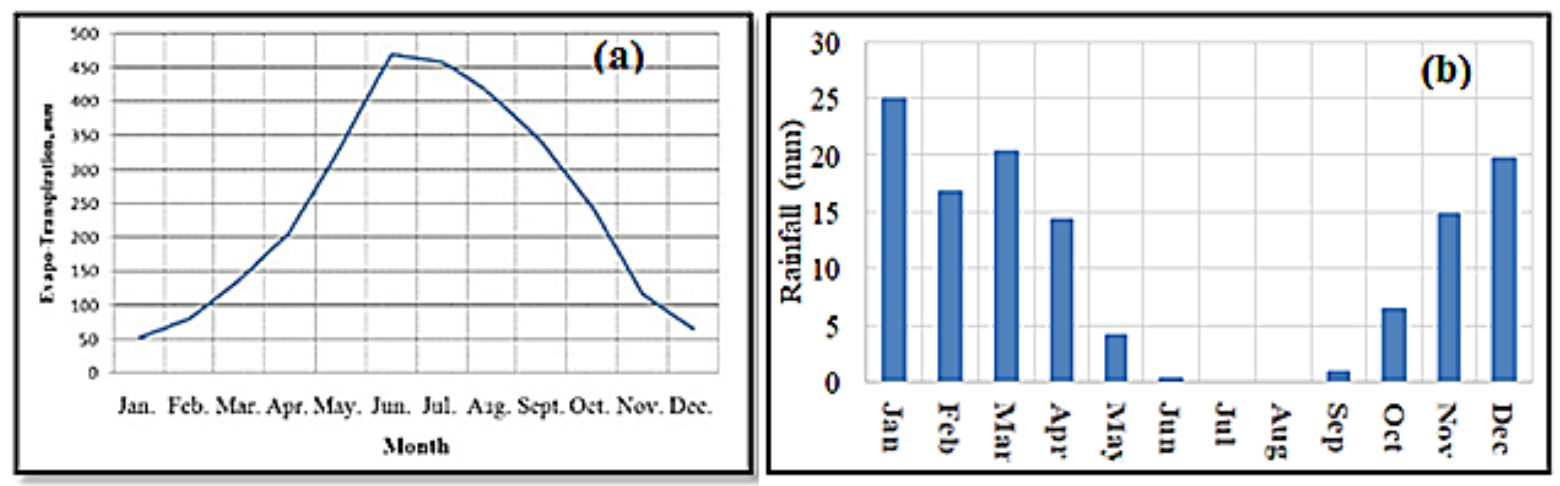

Fig. 5. Evapotranspiration and precipitation of Alsenaf marsh (a - Evapotranspiration and b- Rainfall)

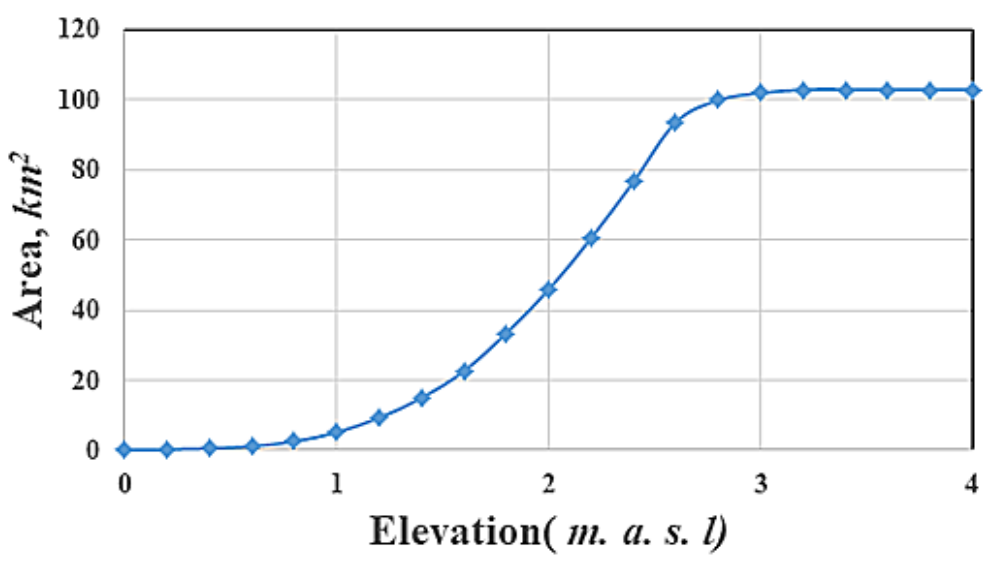

Fig. 6. Curve of the area elevation for Al-Sanaf marsh

\section{Results of hydrodynamic model}

Depending on the hydrological analysis and boundary conditions, the hydrodynamic mathematical model were carried out including the mesh generation, defining the model parameters, calibration processes, and the run results under different operation scenarios. Table 4 shows the results of the hydrodynamic mathematical model under the conditions of four scenarios. The simple deference between the values of outflow in the hydrological analysis and mathematical model occurred because of the deference in the submerged area that was calculated with two methods. Figure 8 shows the distribution of water depth and velocity pattern for all scenarios. The results show that the water depth within the marsh affected by the water surface elevation at the outlet, discharge of the feeders and topography of the marsh. The magnitude and direction of the velocity through the marsh depend on the location and the features of the marsh such as islands, borders and deep waterway. In addition, the velocity magnitude increased at the culverts under railway.

The calculations of the forth scenarios are listed in Table 5 as a sample. Table 6 listed the scenarios of hydrological analysis. The values of the inflow discharges for each scenario were considered as upstream boundary conditions for the hydrodynamic model, while the downstream boundary condition is considered as constant water level at the outlets of the marsh. This elevation for each scenario obtained from area-elevation curve presented in Figure 5 depended up on the selected submerged area. All these scenarios were tested with mathematical models with two locations of outlet for each scenario.

\section{Results of water quality model}

The results of computing the TDS distribution patterns within the Al-Sanaf marsh using the RMA4 model were shown in Figure 9. It can be noted that the distribution of TDS was affected by the discharge and concentration of TDS of the 

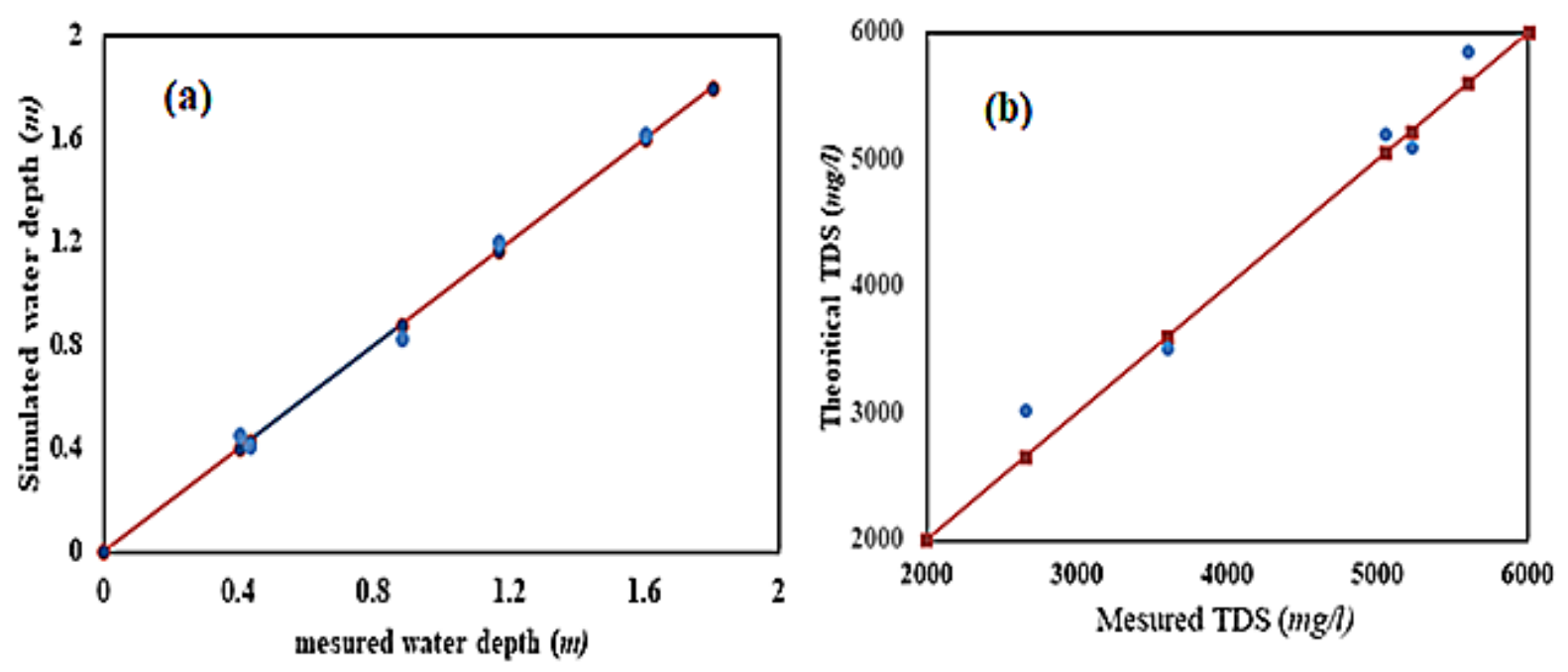

Fig. 7. Calibration of mathematical models (a- Water depth and b- TDS values)

feeders and evapotranspiration. Because of the high concentration of TDS in the Al Khamissiya feeder that feed the marsh from MOD, the marsh was mainly affected by it. The results showed that the concentrations of TDS at the marsh outlet were $6980,5350,3580$ and $8150 \mathrm{mg} / 1$ for four scenarios, respectively. Additionally, it can be noted that the maximum concentration of TDS at the fourth scenario when the percentage of the discharge of Al Khamissiya canal to another feeders is maximum. The concentrations of TDS at the outlet depending on the principle of mass balance were $7325,5502,3509$ and $8505 \mathrm{mg} / 1$ for four scenarios, respectively. From the distribution of concentration of TDS, it can be noted that the water quality deteriorated at the stagnation region where evapotranspiration was high.

\section{CONCLUSIONS}

The deterioration of the Mesopotamian marshlands during the last two decades is an example of the negative impact of human activities on marshlands. Restoring all marshlands will require many years and an array of people and technology. According to the current condition of the feeders and their feeding points into the Al Hammar marsh, they are not suited for restoration in the entire area. Al-Sanaf is part of the Al Hammar marsh; there is no any structure separate between the two marshes. In order to ensure that the marsh is submerged, it must be separated from the Al Hammar marsh by closing the culverts under the security dyke and replaced with uncontrolled weir. The maximum submerged area of the marsh is $100 \mathrm{~km}^{2}$ under any operation conditions while this area reduced to $72 \mathrm{~km}^{2}$ under low flow conditions (minimum inflow from the feeders). The minimum crest level of the weir must not be lower than 2.8 m.a.s.l in order to keep the submerged area within $100 \mathrm{~km}^{2}$. In order to keep the requirement of Al-Sanaf marsh restoration, four scenarios were suggested, in which any added water will go to the Al Hammar marsh. The minimum deteriorated area with high concentration of TDS when the discharge from the Al Khamissiya canal is kept to minimum. If the discharge from the feeders that feed the marsh from Euphrates River is greater than $24 \mathrm{~m}^{3} / \mathrm{s}$, there is no need to feed the marsh from Al Khamissiya canal. This discharge covered the evapotranspiration and

Table 4. The results of the hydrodynamic mathematical model of four scenarios

\begin{tabular}{|c|c|c|c|c|c|}
\hline Scenarios & Submerged area $\mathrm{km}^{2}$ & Inflow $\mathrm{m}^{3} / \mathrm{s}$ & $\begin{array}{c}\text { Evapotranspiration } \\
\mathrm{m}^{3} / \mathrm{s}\end{array}$ & $\begin{array}{c}\text { Outflow } \\
\mathrm{m}^{3} / \mathrm{s}\end{array}$ & $\begin{array}{c}\text { Water surface elevation at } \\
\text { outlet, m.a.m.s.I }\end{array}$ \\
\hline 1 & 100 & 23.4 & 9.28 & 14.3 & 2.8 \\
\hline 2 & 100 & 23.35 & 9.28 & 14.25 & 2.8 \\
\hline 3 & 100 & 33.5 & 9.28 & 24.4 & 2.8 \\
\hline 4 & 72 & 13.1 & 6.68 & 6.53 & 2.4 \\
\hline
\end{tabular}


minimum requirements of outflow to flush the salty water. The minimum concentration of TDS at outlet is $3580 \mathrm{mg} / \mathrm{l}$ when the discharge from Euphrates River is at maximum value.

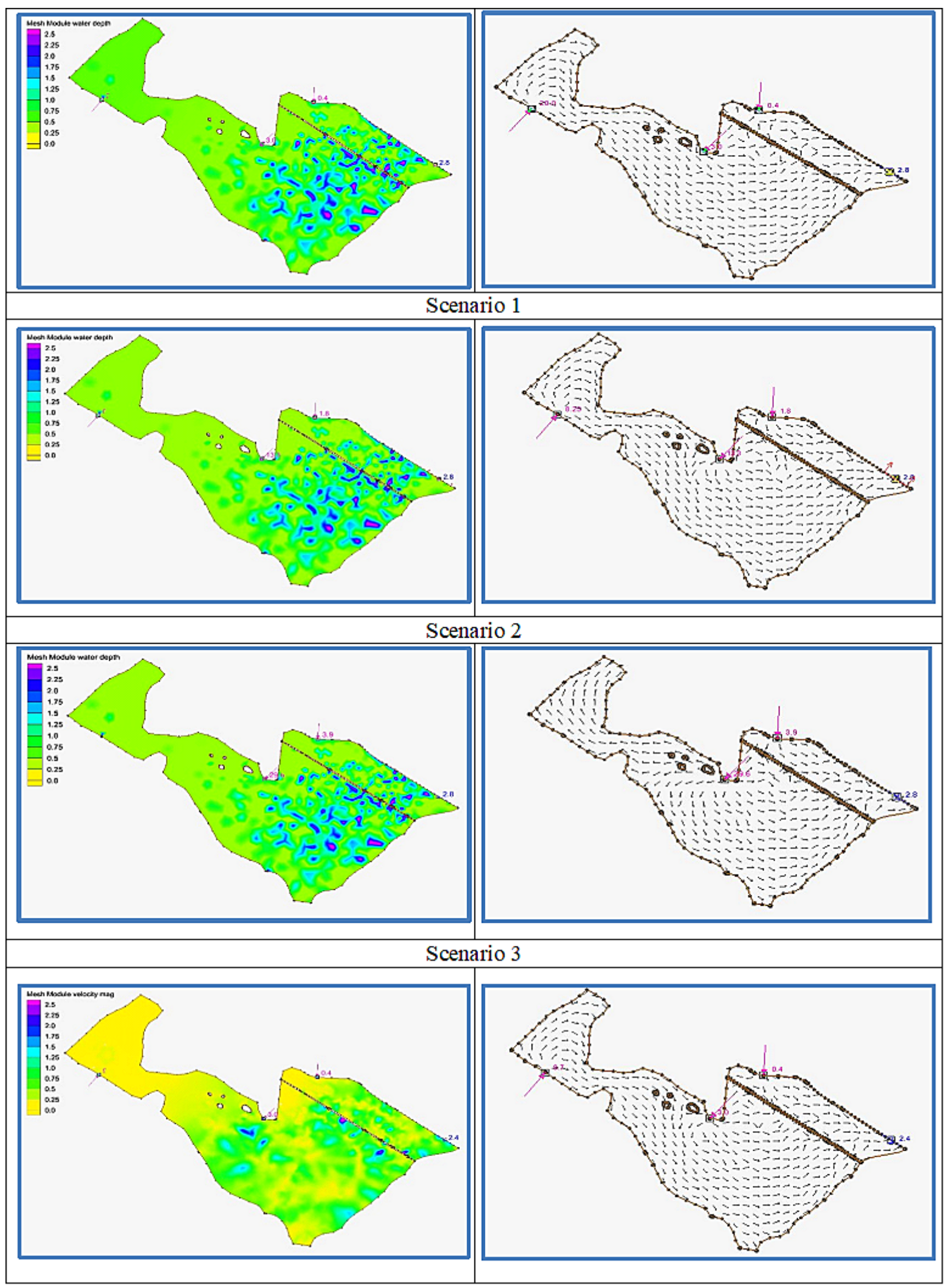

Fig. 8. Water depth and velocity pattern distribution of suggested scenarios in Al-Sanaf marsh 
Table 5. The required inflow and outflow to maintain the area of $72 \mathrm{~km}^{2}$.

\begin{tabular}{|c|c|c|c|c|c|c|}
\hline Month & & $\begin{array}{c}\text { Eto, } \\
\mathrm{mm}\end{array}$ & $\begin{array}{c}\text { Eto, } \\
\mathrm{m}^{3} / \mathrm{s}\end{array}$ & $\begin{array}{c}\text { feeders } \\
\text { Discharge } \\
\mathrm{m}^{3} / \mathrm{s}\end{array}$ & $\begin{array}{c}\text { Discharge of Al Khamissiya } \\
\text { Canal, } \mathrm{m}^{3} / \mathrm{s},\end{array}$ & The outlet Discharge $\mathrm{m}^{3} / \mathrm{s}$ \\
\hline Jan. & 50 & 1.34 & 3.40 & 9.70 & 11.76 \\
\hline Feb. & 75 & 2.23 & 3.40 & 9.70 & 10.87 \\
\hline Mar. & 130 & 3.49 & 3.40 & 9.70 & 9.61 \\
\hline April & 200 & 5.56 & 3.40 & 9.70 & 3.54 \\
\hline May & 350 & 9.41 & 3.40 & 9.70 & 0.0 \\
\hline Jun & & 475 & 13.19 & 3.40 & 9.70 & 2.00 \\
\hline July & & 450 & 12.10 & 3.40 & 9.70 & 3.38 \\
\hline Aug. & 410 & 11.02 & 3.40 & 9.70 & 6.38 \\
\hline Sept. & 350 & 9.72 & 3.40 & 9.70 & 9.77 \\
\hline Oct. & 250 & 6.72 & 3.40 & 9.70 & 11.08 \\
\hline Nov. & 120 & 3.33 & 3.40 & 9.70 & 6.42 \\
\hline Dec. & 75 & 2.02 & 3.40 & 9.70 & 9.70 \\
\hline Averages & & & 6.68 & 3.40 & & \\
\hline
\end{tabular}

Table 6. The scenarios of hydrological analysis

\begin{tabular}{|c|c|c|c|c|c|}
\hline Scenarios & Submerged area $\mathrm{km}^{2}$ & $\begin{array}{c}\text { Discharge from the } \\
\text { Euphrates River, } \mathrm{m}^{3} / \mathrm{s}\end{array}$ & $\begin{array}{c}\text { Average annual discharge } \\
\text { from Al Khamissiya canal, } \\
\mathrm{m} 3 / \mathrm{s}\end{array}$ & $\begin{array}{c}\text { Average } \\
\text { annual Eto, } \\
\mathrm{m}^{3} / \mathrm{s}\end{array}$ & $\begin{array}{c}\text { Average annual } \\
\text { outflow } \\
\mathrm{m}^{3} / \mathrm{s}\end{array}$ \\
\hline 1 & 100 & 3.4 & 20 & 9.28 & 14.12 \\
\hline 2 & 100 & 15.1 & 8.25 & 9.28 & 14.07 \\
\hline 3 & 100 & 33.5 & 0.0 & 9.28 & 24.22 \\
\hline 4 & 72 & 3.4 & 9.7 & 6.68 & 6.42 \\
\hline
\end{tabular}

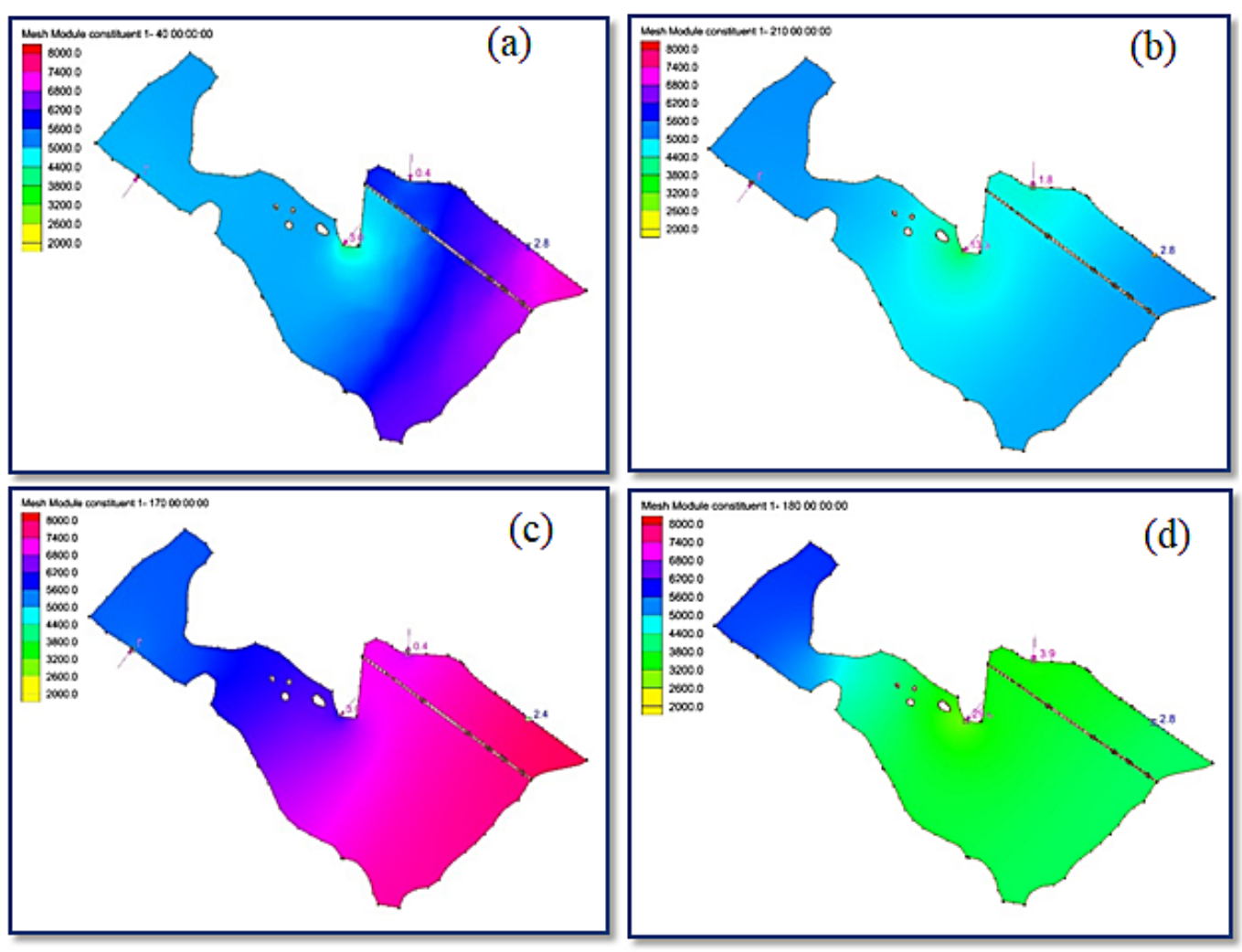

Fig. 9. The results of computing the TDS distribution patterns within Al Sanaf marsh using the RMA4 model Scenario 1, b- Scenario 2, c- Scenario 3 and d- Scenario 4) 


\section{REFERENCES}

1. Al-Ansari, N. (2013). Management of water resources in Iraq: perspectives and prognoses. Engineering, 5(6), 667-684.

2. Al-Ansari, N., \& Knutsson, S. (2011). Possibilities of restoring the Iraqi marshes known as the Garden of Eden. Paper presented at the Water and Climate Change in the MENA-Region: Adaptation, Mitigation and Best Practices 28/04/2011-29/04/2011.

3. Al-Ansari, N., Knutsson, S., Ali, A. (2012). Restoring the Garden of Eden, Iraq. Journal of Earth Sciences and Geotechnical Engineering, 2(1), 53-88.

4. Al-Gburi, H. F. A., Al-Tawash, B. S., \& Al-Lafta, H. S. (2017). Environmental assessment of Al Hammar Marsh, Southern Iraq. Heliyon, 3(2), e00256.

5. Al-Musawi, N. O., Al-Obaidi, S. K., \& Al-Rubaie, F. M. (2018). Evaluating water quality index of al hammar marsh, south of iraq with the application of gis technique. Journal of Engineering Science and Technology, 13(12), 4118-4130.

6. Al Obaidy, A. H. M. J., \& Al-Khateeb, M. (2013). The challenges of water sustainability in Iraq. Engineering and Technology Journal, 31(5 Part (A) Engineering), 828-840.

7. Alhamdani, J. (2014). Location of outlet and operation of the west part of AlHammar Marsh. Ph. D. Thesis, University of Baghdad.

8. Ali, A. A. (2013). Morphology of Tigris River inside Baghdad City. Luleå tekniska universitet.

9. Azhar Al-Saboonchi, Abdul-Razak M. Mohamed, M., A. H., Jawad Alobaidy, Haider S. Abid, \& Maulood, B. K. (2011). On the Current and Restoration Conditions of the Southern Iraqi Marshes: Application of the CCME WQI on East Hammar Marsh Journal of Environmental Protection, 2, 316-322.

10. CRIM. (2010). Possibility of using the water of the main outfall drain to restore AlHammar marsh after operating the pump station in Al Nassiriyah. Final Draft report.

11. Donnell, B. P. (2009). RMA2 WES version 4.5. US army. Engineer Research and Development Center, 277.

12. Foundation, I. (2003). Physical characteristic of Mesopotamian marshlands of southern Iraq. Draft report, Iraq Foundation. 45 pp.

13. Hussain, N., \& Ali, T. (2006). Trophic nature and feeding relationships among Al Hammer marsh fishes, southern Iraq. Marsh Bulletin, 1(1), 9-18.
14. Kadhim, A. J. (2005). Water quality monitoring of Abu Zarak marsh in southern in Iraq (after drying) (Vol. Master thesis): Al-Mustansiriya University.

15. Kugaprasatham, S., Al-Lami, A., \& Aoki, C. (2014). Environmental management of the Iraqi marshlands in the post-conflict period Water and post-conflict peacebuilding (pp. 135-154): Routledge.

16. Marghany, M., Hasab, H. A., Mansor, S., \& Shariff, A. R. B. M. (2016). Developing hydrological model for water quality in Iraq marshes zone using Landsat-TM. Paper presented at the IOP Conference Series: Earth and Environmental Science.

17. Ministry of Water Resources, C. o. R. o. t. I. M., CRIM, \& . (2006). Study The Rehabilitation of Al Huwayza Marsh Ecological Syste.

18. Mohamed, A.-R. M., \& Hussain, N. A. (2012). Evaluation of Fish assemblage environment in east Hammar using Integrated Biological Index. basrah journal of science, 30(2B Environmental Conference), 87-105.

19. Najah, A., Mohamed, A., Al Noo, S., Mutlak, F., Abed, I., \& Coad, B. (2009). Structure and ecological indices of fish assemblages in the recently restored Al Hammar Marsh, southern Iraq approaches. BioRisk Journal, 3, 173-186.

20. Novikov, A., \& Bagtzoglou, A. C. (2006). Hydrodynamic model of the lower hudson river estuarine system and its application for water quality management. Water resources management, 20(2), 257-276.

21. Richardson, C. J. (2016). Mesopotamian Marshes of Iraq. The Wetland Book: II: Distribution, Description and Conservation, 1-11.

22. Richardson, C. J., \& Hussain, N. A. (2006). Restoring the Garden of Eden: An Ecological Assessment of the Marshes of Iraq. BioScience 477, 56 (6).

23. UNEP-DTIE-IETC, C. (2009). UNEP-UNESCO project and World Heritage Programme: Project overview. Paper presented at the Kick-off meeting: Natural Cultural Management of the Iraqi Marshlands as World Heritage. Amman, Jordan.

24. USGS. (1976). Techniques of Water-Resources Investigations of the United States Geological Survey, Chapter A8, Discharge Measurements at Gauging Stations.

25. Yasir, R. A., Rahi, K. A., \& Abudi, Z. N. (2018). Water budget for abu zirig marsh in Southern Iraq. Journal of Engineering and Sustainable Development, 22(1), 25-33. 